Article

\title{
Shear Strength and Aging Characteristics of Sn-3.0Ag-0.5Cu/Cu Solder Joint Reinforced with $\mathrm{ZrO}_{2}$ Nanoparticles
}

\author{
Sri Harini Rajendran, Seung Jun Hwang and Jae Pil Jung * \\ Department of Materials Science and Engineering, University of Seoul, 163 Seoulsiripdae-ro, Dongdaemun-gu, \\ Seoul 02504, Korea; harini.phys@gmail.com (S.H.R.); hsm6136@gmail.com (S.J.H.) \\ * Correspondence: jpjung@uos.ac.kr
}

Received: 2 September 2020; Accepted: 27 September 2020; Published: 28 September 2020

\begin{abstract}
This study investigates the shear strength and aging characteristics of $\mathrm{Sn}-3.0 \mathrm{Ag}-0.5 \mathrm{Cu}$ (SAC 305)/Cu joints by the addition of $\mathrm{ZrO}_{2}$ nanoparticles (NPs) having two different particle size: $5-15 \mathrm{~nm}$ $\left(\mathrm{ZrO}_{2} \mathrm{~A}\right)$ and $70-90 \mathrm{~nm}\left(\mathrm{ZrO}_{2} \mathrm{~B}\right)$. Nanocomposite pastes were fabricated by mechanically mixing $\mathrm{ZrO}_{2} \mathrm{NPs}$ and the solder paste. $\mathrm{ZrO}_{2} \mathrm{NPs}$ decreased the $\beta$-Sn grain size and $\mathrm{Ag}_{3} \mathrm{Sn}$ intermetallic compound (IMC) in the matrix and reduced the $\mathrm{Cu}_{6} \mathrm{Sn}_{5}$ IMC thickness at the interface of lap shear SAC 305/Cu joints. The effect is pronounced for $\mathrm{ZrO}_{2} \mathrm{~A}$ NPs added solder joint. The solder joints were isothermally aged at $175^{\circ} \mathrm{C}$ for $24,48,144$ and $256 \mathrm{~h}$. NPs decreased the diffusion coefficient from $1.74 \times 10^{-16} \mathrm{~m} / \mathrm{s}$ to $3.83 \times 10^{-17} \mathrm{~m} / \mathrm{s}$ and $4.99 \times 10^{-17} \mathrm{~m} / \mathrm{s}$ for $\mathrm{ZrO}_{2} \mathrm{~A}$ and $\mathrm{ZrO}_{2} \mathrm{~B}$ NPs added SAC 305/Cu joints respectively. The shear strength of the solder joints decreased with the aging time due to an increase in the thickness of interfacial IMC and coarsening of $\mathrm{Ag}_{3} \mathrm{Sn}$ in the solder. However, higher shear strength exhibited by SAC $305-\mathrm{ZrO}_{2} \mathrm{~A} / \mathrm{Cu}$ joints was attributed to the fine $\mathrm{Ag}_{3} \mathrm{Sn} \mathrm{IMC}^{\prime} \mathrm{s}$ dispersed in the solder matrix. Fracture analysis of $\mathrm{SAC} 305-\mathrm{ZrO}_{2} \mathrm{~A} / \mathrm{Cu}$ joints displayed mixed solder/IMC mode upon $256 \mathrm{~h}$ of aging.
\end{abstract}

Keywords: nanocomposite solder; $\mathrm{Ag}_{3} \mathrm{Sn}$ intermetallic compound; aging; shear strength

\section{Introduction}

In the expanding information era, research has largely contributed to the development of high performance integrated circuit (IC). Meanwhile, the integration of the IC chips and their long term reliability remains a barrier in preventing the electronic industries to achieve their maximum efficiency [1]. Although many innovative joining techniques have been evolved, soldering is an essential joining step followed in the advanced IC packaging types such as through-hole technology, flip-chip and ball grid arrays [2]. Sn-Ag-Cu, Sn-Bi, $\mathrm{Sn}-\mathrm{In}, \mathrm{Sn}-\mathrm{Cu}$ and $\mathrm{Au}-\mathrm{Sn}$ are some of the potential lead-free solders used in the microelectronic packaging [3]. Among these Sn-3 wt.\% Ag-0.5 wt.\% Cu (SAC 305) solder is the primary candidate because their moderate melting temperature, good solderability, electrical performance, high-temperature resistance and mechanical properties such as strength and ductility [3,4]. The potential drawback in SAC 305 solder is the excessive growth of the $\mathrm{Cu}-\mathrm{Sn}\left(\mathrm{Cu}_{6} \mathrm{Sn}_{5}\right.$ and $\mathrm{Cu}_{3} \mathrm{Sn}$ ) inter-metallic compounds (IMC) at the solder/Cu interface due to the reactive wetting of Sn on copper substrate [4]. Alloying and nanoparticles (NPs) addition are the methods adopted in general to refine the IMC and to enhance the solderability and mechanical properties of SAC solder [3]. Presently, research in ceramic NPs reinforced SAC solder is given more attention owing to their stability in the solder matrix and the positive contribution in $\mathrm{Ag}_{3} \mathrm{Sn} \mathrm{IMC}$ refinement, reliability as well as the suppression of the $\mathrm{Cu}_{6} \mathrm{Sn}_{5}$ IMC at the solder/Cu interface [3-9]. Tsao et al. and Chuang et al. observed an overall increase in mechanical properties such as yield strength, tensile strength and micro-hardness 
in the SAC 305 solder alloy after the addition of $\mathrm{TiO}_{2}$ and $\mathrm{Al}_{2} \mathrm{O}_{3} \mathrm{NPs}[5,6]$. Similar enhancement in mechanical properties are also reported by various authors for the addition of $\mathrm{AlN}$ [7], $\mathrm{SnO}_{2}$ [8] and $\mathrm{ZrO}_{2}$ [9] NPs in SAC solder by various authors.

However, the thickness of $\mathrm{Cu}_{6} \mathrm{Sn}_{5}$ and $\mathrm{Cu}_{3} \mathrm{Sn}$ IMCs formed at the interface of SAC solder and $\mathrm{Cu}$ substrate during manufacturing, repair and transportation decides the reliability of the solder joints [10]. With miniaturization, the reliability becomes the primary concern in fine pitch solder joints as the high current density and Joule heating drives the diffusion of $\mathrm{Cu}$ and $\mathrm{Sn}$ atoms along the interface [11]. Prolonged service time and elevated service temperature of the component results in a higher volume fraction of the brittle IMC at the interface, thus affecting the reliability of the fine-pitch solder joints [10,11]. By adding $\mathrm{TiO}_{2} \mathrm{NPs}$ in SAC solder, Chang et al. [12] observed an overall reduction in the thickness of IMC from $4.44 \mu \mathrm{m}$ to $2.78 \mu \mathrm{m}$ due to the adsorption of nanoparticles at the SAC/Cu interface. Meanwhile, the addition of $\mathrm{ZrO}_{2}$ NPs also suppressed the IMC thickness and improved the joint strength of the $\mathrm{SAC} / \mathrm{Cu}$ interface [9]. Aspalter et al. [13] reported that $\mathrm{ZrO}_{2}, \mathrm{SiO}_{2}, \mathrm{TiO}_{2}$ and $\mathrm{Al}_{2} \mathrm{O}_{3} \mathrm{NPs}$ doped flux has decreased the $\mathrm{Cu}$-Sn growth kinetics and enhanced the shear strength of solder/Cu joints. Gain et al. [14] reported that $\mathrm{SAC} / \mathrm{Cu}$ with $\mathrm{ZrO}_{2} \mathrm{NPs}$ has higher activation energy for total IMC formation which contribute to suppression effect as compared with monolithic SAC/Cu joints. Shang et al. [15] reported that $\mathrm{Cu}$-Sn IMC suppression effect is more pronounced in small size $\mathrm{TiO}_{2} \mathrm{NPs}$ having higher surface to volume ratio.

Although many investigations have proven the fact that NPs enhance the overall mechanical properties and slow down the growth $\mathrm{Cu}$-Sn IMC growth at the interface, only NPs type and their addition level were considered during the materials design. However, at a constant addition level, the effect of nanoparticle size on the reliability and their aging characteristics has not been reported yet. $\mathrm{ZrO}_{2} \mathrm{NPs}$ are chosen in the present work due to their effective surface active nature with good mechanical properties and chemical stability [9]. Among the various reliability testing methods, lap shear test resembles the real-life loading configuration experienced by the solder joints $[8,16]$. In the present study, lap shear test has been adopted to investigate the microstructure, $\mathrm{Cu}$-Sn IMC growth and the shear strength of isothermally aged $\mathrm{ZrO}_{2}$ added SAC 305/Cu joints with regard to the NPs size.

\section{Materials and Methods}

\subsection{Sample Preparation}

Type 4 commercial SAC 305 solder paste of 99.99\% purity (Alpha assembly solutions, Siheung-Si, South Korea) with RMA (Rosin Mildly Activated) flux was used as a base solder. $\mathrm{ZrO}_{2} \mathrm{NPs}$ of $99.5 \%$ purity (Ditto Technology Co. Ltd., Gumpo-Si, South Korea) with an average particle size of 5-15 nm (hereafter referred as $\mathrm{ZrO}_{2} \mathrm{~A}$ ) and $70-90 \mathrm{~nm}$ (hereafter referred as $\mathrm{ZrO}_{2} \mathrm{~B}$ ) were used as additives to the base solder. Figure $1 \mathrm{a}$ and $\mathrm{b}$ shows field emission scanning electron microscope image of as-purchased spherical $\mathrm{ZrO}_{2} \mathrm{~A}$ and $\mathrm{ZrO}_{2} \mathrm{~B}$ NPs respectively. SAC 305-0.2 wt.\% of $\mathrm{ZrO}_{2} \mathrm{~A}$ and SAC 305-0.2 wt.\% of $\mathrm{ZrO}_{2} \mathrm{~B}$ nanocomposite solders (hereafter referred as SAC $305-\mathrm{ZrO}_{2} \mathrm{~A}$ and $\mathrm{SAC} 305-\mathrm{ZrO}_{2} \mathrm{~B}$ respectively) were prepared by mechanical mixing method. Accurately weighted $\mathrm{ZrO}_{2} \mathrm{NPs}$ and the solder paste were mechanically mixed using a centrifugal mixer (THINKY, CA, USA) at 2000 RPM for 2 min. The sample was air cooled at an interval of $30 \mathrm{~s}$ to avoid the excessive heat generated during mixing. 

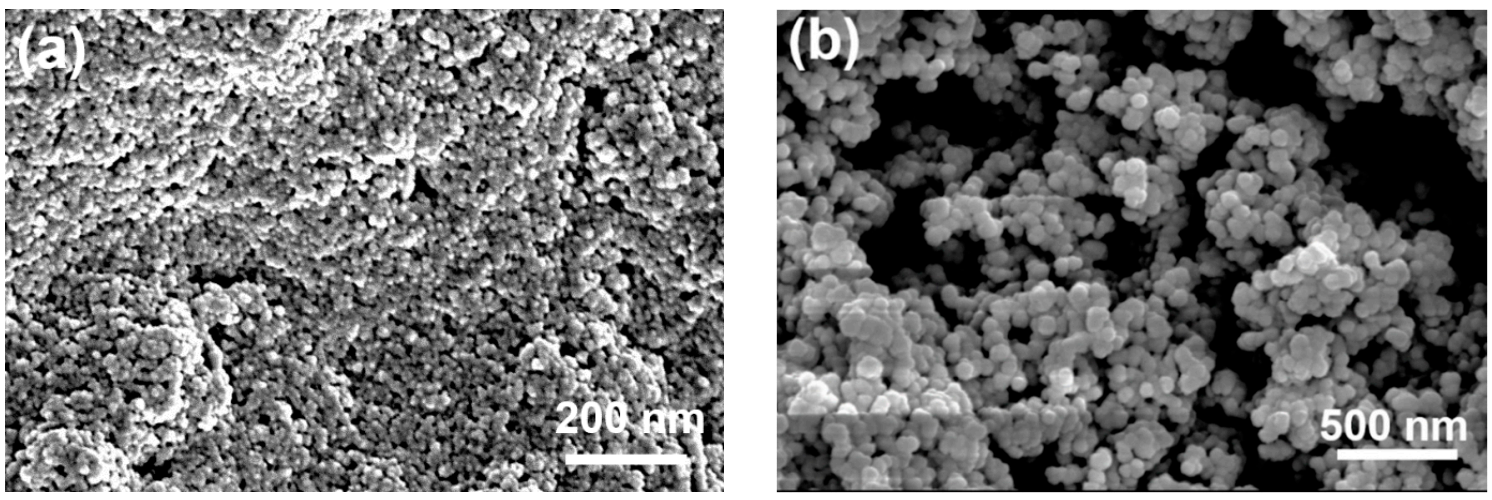

Figure 1. Field emission scanning electron microscopy image of as-received $\mathrm{ZrO}_{2} \mathrm{NPs}$ of varying size: (a) $\mathrm{ZrO}_{2} \mathrm{~A}(5-15 \mathrm{~nm})$ and (b) $\mathrm{ZrO}_{2} \mathrm{~B}(70-90 \mathrm{~nm})$ nanoparticles.

\subsection{Soldering and Microstructure Analysis}

Copper plates $(50 \mathrm{~mm} \times 10 \mathrm{~mm} \times 1 \mathrm{~mm}$ ) were finely polished using $\mathrm{SiC}$ abrasive to make a uniform surface and to remove the surface contaminants. Flowingly, copper plates were soaked in $5 \mathrm{Vol} . \% \mathrm{HCl}$ solution to get rid of the oxide layer and were ultrasonically cleaned with distilled water. Lap shear joints were fabricated as explained in Section 2.3. The joints were thermally aged in an oven at $175^{\circ} \mathrm{C}$ for up to $256 \mathrm{~h}$. For IMC analysis, the joints were mounted in epoxy, cross-sectioned and polished using standard metallographic techniques. Prior to scanning electron microscopy (SEM) analysis, the polished joints were etched in a solution containing $3 \mathrm{Vol} . \% \mathrm{HCl}, 5 \mathrm{Vol} . \% \mathrm{HNO}_{3}$ and $92 \mathrm{Vol} \%$ $\mathrm{CH}_{3} \mathrm{OH}$. The microstructure of the solder joint, IMC thickness and the fractured surfaces after shear test were analyzed using analytical scanning SEM (JEOL JSM-6010PLUS, Tokyo, Japan) attached with energy dispersive spectrometer (EDS). The average thickness of IMC at the interface was calculated from the ratio of the IMC area to its length calculated from SEM image. The $\beta$-Sn grain size, eutectic area percentage, $\mathrm{Ag}_{3} \mathrm{Sn}$ size and their inter-phase spacing were measured using Image-Pro Plus 6.0 program. Each data is an average value calculated from 20 high magnification images randomly chosen during SEM analysis.

\subsection{Joint Strength Evaluation and Fractography}

To prepare single lap shear joints, $200 \mu \mathrm{m}$ thick nanocomposite solder paste was applied on the copper plates using a customized mask. Aluminum sheet having a thickness $150 \mu \mathrm{m}$ was used as spacers to achieve uniformly thick solder joints during reflow since the joint clearance affects bond strength prominently. The specimens were clamped and reflowed at $25^{\circ} \mathrm{C}$ for $90 \mathrm{~s}$ in a hot plate. After reflow, Al spacers were removed, extruded solder and flux residue at the edges were polished and cleaned with ethanol. Figure 2 schematically explains the fabrication of single lap shear test specimens. Shear test of the SAC 305/Cu joints was performed using AUTO-TENFORCE M/C (Korea-tech) tensile testing machine in room temperature at a fixed rate of $3.0 \mathrm{~mm} / \mathrm{min}$. For each condition, average value of the five samples were reported. The fractured surface was analyzed using SEM and EDS. 


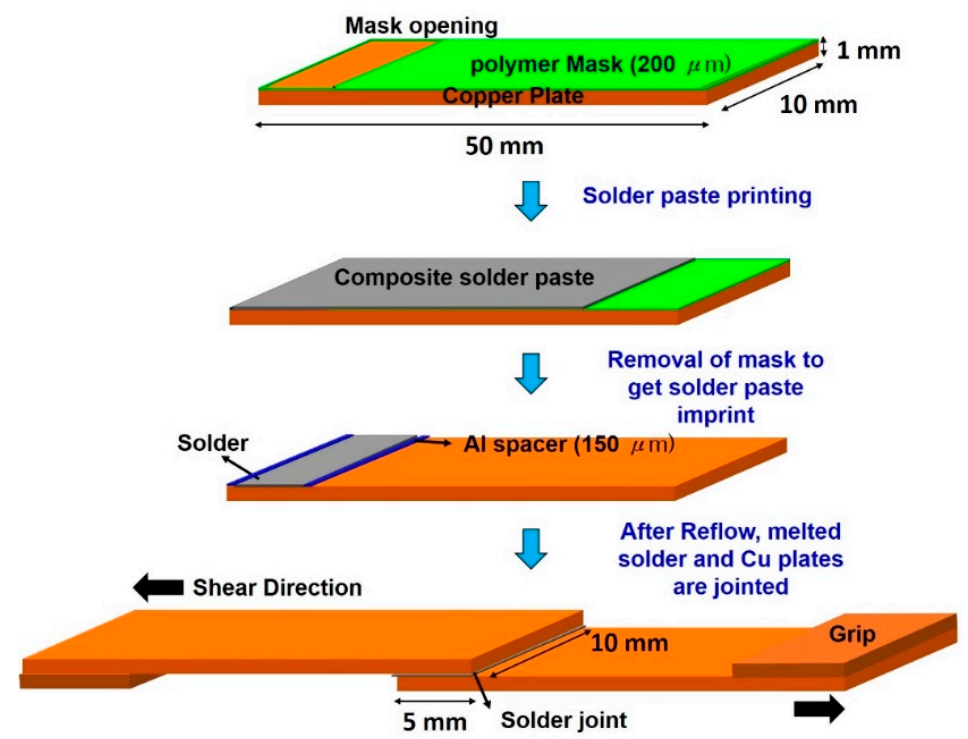

Figure 2. Schematic illustration for the fabrication of lap shear SAC 305/Cu joints.

\section{Results and Discussion}

\subsection{Effect of $\mathrm{ZrO}_{2} \mathrm{NPs}$ Size on the Microstructure of SAC 305/Cu Shear Joints}

Figure 3a-f shows the as-reflow microstructure of monolithic SAC 305/Cu and $\mathrm{ZrO}_{2}$ NPs added SAC 305/Cu joints. Figure 3a and b represents the microstructure of monolithic SAC 305/Cu joint and the corresponding high magnification image respectively. SAC 305 eutectic alloy upon solidification yields three phases: a needle-like $\mathrm{Ag}_{3} \mathrm{Sn}$ IMC phase (white contrast), an irregular polygon like $\mathrm{Cu}_{6} \mathrm{Sn}_{5}$ IMC phase (dark grey contrast) distributed within the dendritic $\beta$-Sn solid solution phase (light grey contrast) as shown in Figure $3 \mathrm{~b}$. The average grain size of $\beta$-Sn is $21.1 \pm 3.3 \mu \mathrm{m}$ and the eutectic area is $16.6 \%$. The average length and width of needle-like $\mathrm{Ag}_{3} \mathrm{Sn}$ phase are $4.9 \pm 1.2 \mu \mathrm{m}$ and $0.63 \pm 0.08 \mu \mathrm{m}$ respectively. The average spacing between the adjacent $\mathrm{Ag}_{3} \mathrm{Sn}$ phase in eutectic structure is $1.9 \pm 0.6 \mu \mathrm{m}$. 

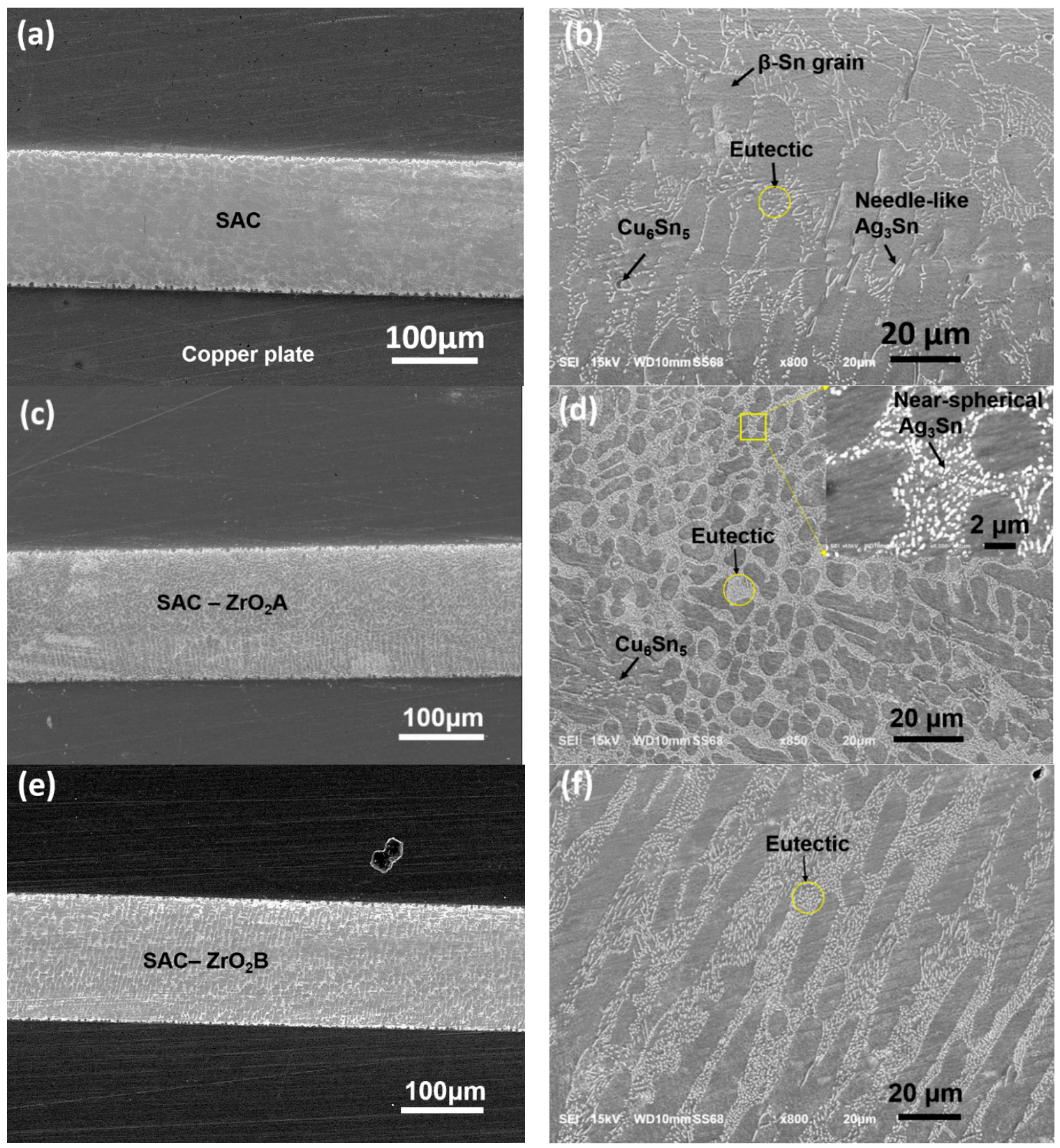

Figure 3. Scanning electron microscope (SEM) micrograph of as-reflowed (a) SAC 305/Cu joint and (b) the corresponding microstructure, (c) SAC 305- $\mathrm{ZrO}_{2} \mathrm{~A} / \mathrm{Cu}$ joint and (d) the corresponding microstructure, (e) SAC 305- $\mathrm{ZrO}_{2} \mathrm{~B} / \mathrm{Cu}$ joint and (f) the corresponding microstructure.

As observed from Figure $3 \mathrm{c}-\mathrm{f}$, a significant refining is seen in the microstructure of as-reflowed $\mathrm{SAC} 305-\mathrm{ZrO} 2 / \mathrm{Cu}$ joints, most notably in $\mathrm{SAC} 305-\mathrm{ZrO}_{2} \mathrm{~A} / \mathrm{Cu}$ joint. The area of $\mathrm{Ag}_{3} \mathrm{Sn}$ and $\beta-\mathrm{Sn}$ eutectic network has increased and the morphology of $\mathrm{Ag}_{3} \mathrm{Sn}$ IMC has been modified from needle-like to a near-spherical in $\mathrm{ZrO}_{2}$ added SAC 305/Cu joints. Also, the average grain size of $\beta$-Sn is decreased and the irregular polygon like $\mathrm{Cu}_{6} \mathrm{Sn}_{5}$ has been refined with the addition of $\mathrm{ZrO}_{2}$ nanoparticles as shown in Figure $3 b$,d. Table 1 enlists the average values of $\beta$-Sn grain size, eutectic area percentage, $\mathrm{Ag}_{3} \mathrm{Sn}$ size and their inter-phase spacing obtained from the addition of $\mathrm{ZrO}_{2} \mathrm{NPs}$ in SAC 305/Cu joint. Each data is an average value calculated from 20 high magnification images randomly chosen during SEM analysis. From the table, it is clear that the refinement effect is higher in the microstructure of SAC $305-\mathrm{ZrO}_{2} \mathrm{~A} / \mathrm{Cu}$ solder joint. When $\mathrm{ZrO}_{2} \mathrm{~B}$ NPs are added, the $\beta$-Sn grain size and $\mathrm{Ag}_{3} \mathrm{Sn}$ IMC size are $11.3 \pm 4.1 \mu \mathrm{m}$ and $1.0 \pm 0.5 \mu \mathrm{m}$ respectively which is $46 \%$ and $62 \%$ reduction as compared with the 
monolithic SAC solder. Whereas the grain size reduction of $\beta-\mathrm{Sn}$ and $\mathrm{Ag}_{3} \mathrm{Sn}$ in $\mathrm{ZrO}_{2} \mathrm{~A}$ added solder is $83 \%$ and $84 \%$ as compared with the monolithic SAC. These results reveal that at the constant addition level, smaller $\mathrm{ZrO}_{2}$ NPs had a significant influence in the refinement of SAC 305 solder.

Table 1. Average grain size, $\mathrm{Ag}_{3} \mathrm{Sn}$ spacing and eutectic area percentage for the as-reflow monolithic and $\mathrm{ZrO}_{2}$ reinforced $\mathrm{SAC} / \mathrm{Cu}$ joint.

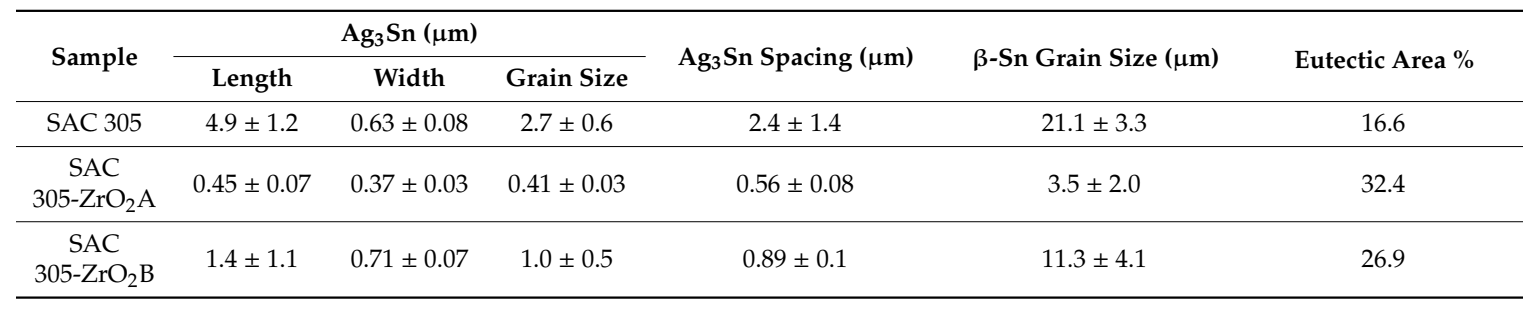

Consistent with above results Tsao et al. [17] have reported that adding $\mathrm{Al}_{2} \mathrm{O}_{3} \mathrm{NPs}$ has shown an overall refinement and increased eutectic network area in SAC 305 solders. Similarly, noticeable modification of eutectic $\mathrm{Ag}_{3} \mathrm{Sn}$ phase from needle-like to spherical-like has been observed for the addition of $\mathrm{TiO}_{2} \mathrm{NPs}$ in SAC solder [5]. El-Daly et al. [18] has showed that addition of SiC nanoparticles in SAC 105 solder has resulted in a smaller $\beta$-Sn sub-grains. Effect of NPs in microstructural refinement in SAC solder has been studied by many researchers and explained qualitatively by the adsorption of surface-active material during the heterogeneous nucleation [17-20]. Upon melting, stable $\mathrm{ZrO}_{2} \mathrm{NPs}$ remain dispersed in the molten solder. NPs are considered as surface active materials due to their high surface to volume ratio [19]. During solidification, the surface-active NPs are enriched along the phase boundaries and gets adsorbed on the growing plane, $\mathrm{k}$. After the adsorption of surface-active material that is, $\mathrm{ZrO}_{2} \mathrm{NPs}$ in this case, the surface free energy of the growing crystal plane k becomes [20]:

$$
\sum_{k} \gamma_{c}^{k} A_{k}=\sum_{k} \gamma_{0}^{k} A_{k}-R T \sum_{k} A_{k} \int_{0}^{c} \frac{\Gamma^{k}}{c} d c
$$

where $c$ is the concentration of the surface-active material, $\gamma_{c}^{k}$ and $\gamma_{0}^{k}$ are the surface tension of the crystal plane $\mathrm{k}$ with and without the adsorption of surface-active NPs. $A_{k}$ is the area of the plane $k$, $\Gamma^{k}$ the amount of surface-active NPs adsorbed at the plane $k$ given by,

$$
\Gamma^{k}=-\frac{c}{R T} \frac{d \gamma^{k}}{d c}
$$

where $R$ and $T$ are the molar gas constant and the absolute temperature respectively. In order to get the plane $k$ to achieve a minimum surface free energy Equation (1) has to be minimum,

$$
\sum_{k} \gamma_{0}^{k} A_{k}-R T \sum_{k} A_{k} \int_{0}^{c} \frac{\Gamma^{k}}{c} d c \rightarrow \min
$$

where $\sum_{k} \gamma_{0}^{k} A_{k}$ term is independent of the concentration of surface-active material and hence assumed to be constant. Hence,

$$
R T \sum_{k} A_{k} \int_{0}^{c} \frac{\Gamma^{k}}{c} d c \rightarrow \text { max. }
$$

For this condition to occur, the crystal plane with the maximum surface tension should grow faster and the same time should adsorb maximum number of surface-active NPs. However, increase in adsorption of surface-active NPs tends to decrease the growth rate of the crystal plane k [19,20]. In $\mathrm{Sn}-\mathrm{Ag}$ eutectic alloy, $\mathrm{Ag}_{3} \mathrm{Sn}$ is supposed to form during the onset of eutectic reaction wherein nucleating $\mathrm{Ag}_{3} \mathrm{Sn}$ crystal act as an epitaxial sink for the $\mathrm{Ag}$ and $\mathrm{Sn}$ atoms. Therefore, higher growth rate of $\mathrm{Ag}_{3} \mathrm{Sn}$ crystals in the eutectic melt which results in a needle-like morphology [9]. In $\mathrm{ZrO}_{2}$ 
NPs added solder, the dispersed nanoparticles in the eutectic melt gets adsorbed on the $\mathrm{Ag}_{3} \mathrm{Sn}$ IMC nucleating crystals thereby decreasing their growth rate resulting in near-spherical morphology.

Pronounced refining observed in the microstructure of SAC $305-\mathrm{ZrO}_{2} \mathrm{~A} / \mathrm{Cu}$ joints as compared with the $\mathrm{SAC} 305-\mathrm{ZrO}_{2} \mathrm{~B} / \mathrm{Cu}$ joints can be attributed to the higher surface to volume ratio of smaller NPs. Adsorption is a surface dominated phenomenon where a high surface to volume ratio of smaller $\mathrm{ZrO}_{2} \mathrm{~A}$ NPs can enhance their adsorption effect on the growing plane of $\mathrm{Ag}_{3} \mathrm{Sn}$. Moreover, at a constant addition level, the number of $\mathrm{ZrO}_{2} \mathrm{~A}$ NPs will be more in the solder as compared to $\mathrm{ZrO}_{2} \mathrm{~B}$ NPs. Therefore, the amount of $\mathrm{ZrO}_{2} \mathrm{~A}$ NPs getting adsorbed on a growing $\mathrm{Ag}_{3} \mathrm{Sn}$ crystal plane $\mathrm{k}$ will be more and consequently shows a better refinement of $\beta$-Sn and $\mathrm{Ag}_{3} \mathrm{Sn}$ phases.

\subsection{Effect of $\mathrm{ZrO}_{2} \mathrm{NPs}$ Size on the Interfacial $\mathrm{Cu}_{6} \mathrm{Sn}_{5}$ Evolution in SAC 305/Cu Shear Joints}

Figure 4a-c displays the $\mathrm{Cu}_{6} \mathrm{Sn}_{5}$ IMC formed at the interface of as-reflowed SAC 305/Cu, $\mathrm{SAC} 305-\mathrm{ZrO}_{2} \mathrm{~A} / \mathrm{Cu}$ and $\mathrm{SAC} 305-\mathrm{ZrO}_{2} \mathrm{~B} / \mathrm{Cu}$ joints respectively. The thickness of $\mathrm{Cu}_{6} \mathrm{Sn}_{5} \mathrm{IMC}$ layer (grey contrast) at the interface of solder joints reduced with the addition of $\mathrm{ZrO}_{2} \mathrm{NPs}$. A scalloped $\mathrm{Cu}_{6} \mathrm{Sn}_{5}$ IMC with a thickness of $2.6 \pm 0.9 \mu \mathrm{m}$ and $1.7 \pm 0.5 \mu \mathrm{m}$ was observed at the interface of monolithic SAC 305/Cu and SAC 305- $\mathrm{ZrO}_{2} \mathrm{~A} / \mathrm{Cu}$ joint respectively. Furthermore, the width of the $\mathrm{Cu}_{6} \mathrm{Sn}_{5}$ scallop appears to be smaller in $\mathrm{SAC} 305-\mathrm{ZrO}_{2} \mathrm{~A} / \mathrm{Cu}$ interface compared to that of monolithic SAC $305 / \mathrm{Cu}$. On contrast, faceted $\mathrm{Cu}_{6} \mathrm{Sn}_{5}$ IMC with a thickness of $2.1 \pm 0.7 \mu \mathrm{m}$ was observed at the interface of SAC 305- $\mathrm{ZrO}_{2} \mathrm{~B} / \mathrm{Cu}$ joint. Scallop to faceted transition in $\mathrm{Cu}_{6} \mathrm{Sn}_{5} \mathrm{IMC}$ has been previously reported for the addition of $\mathrm{TiO}_{2}$ and $\mathrm{Al}_{2} \mathrm{O}_{3}$ nanoparticles [15,17]. Thinner $\mathrm{Cu}_{6} \mathrm{Sn}_{5} \mathrm{IMC}$ grains were formed at the $\mathrm{Sn} / \mathrm{Cu}$ interface with the addition of $5 \mathrm{~nm}$ sized $\mathrm{TiO}_{2} \mathrm{NPs}_{\text {se compared to the } 50 \mathrm{~nm} \mathrm{TiO}}$ NPs [17]. In consistent with previous reports, the suppression of $\mathrm{Cu}_{6} \mathrm{Sn}_{5}$ thickness at the interface is more noticeable for SAC 305 solder reinforced with smaller $\mathrm{ZrO}_{2} \mathrm{~A}$ NPs.
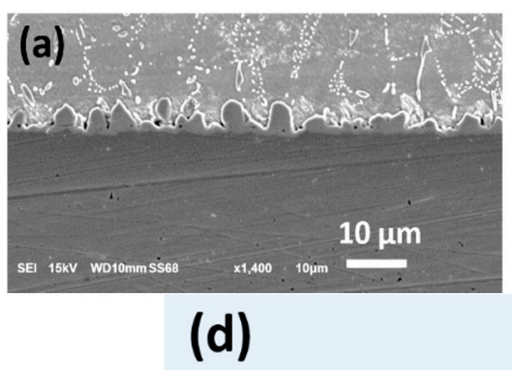

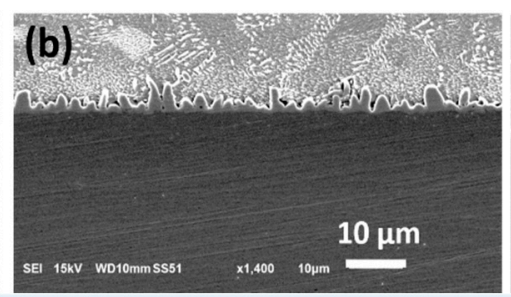

$\mathrm{ZrO}_{2} \mathrm{NPS}$ (5-15 nm)

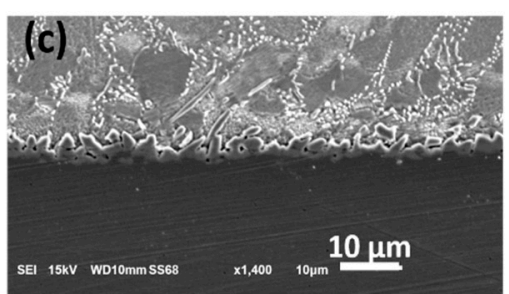

$\mathrm{ZrO}_{2} \mathrm{NPs}$ $(70-90 \mathrm{~nm})$

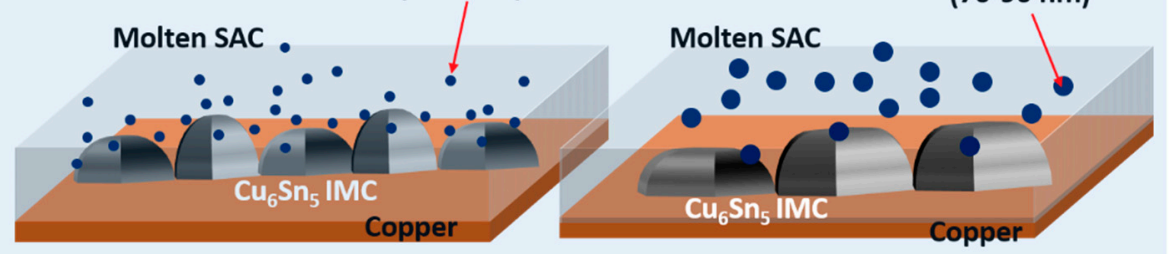

Figure 4. SEM micrograph showing $\mathrm{Cu}_{6} \mathrm{Sn}_{5} \mathrm{IMC}$ layer at the interface of as-reflowed (a) SAC 305/Cu joint, (b) SAC 305-ZrO2A/Cu joint, (c) SAC 305-ZrO2B/Cu joint and (d) Schematic illustration for the influence of smaller $\mathrm{ZrO}_{2} \mathrm{~A}$ and larger $\mathrm{ZrO}_{2} \mathrm{~B}$ NPs on the $\mathrm{Cu}_{6} \mathrm{Sn}_{5} \mathrm{IMC}$ growth.

Analogous to the refinement of $\mathrm{Ag}_{3} \mathrm{Sn}$ as explained in Section 3.1, $\mathrm{Cu}_{6} \mathrm{Sn}_{5} \mathrm{IMC}$ suppression at the interface can also be explained with the theory of adsorption of surface-active material [21]. The propensity of adsorption (referred as equilibrium adsorption constant $\mathrm{K}^{0}$ ) for a surface-active NPs with different dimensions $K_{R_{A}}^{0}$ and $K_{R_{B}}^{0}$ is given by [17],

$$
\frac{K_{R_{A}}^{0}}{K_{R_{B}}^{0}}=\exp \left\{-\frac{3 V_{m}\left(\gamma_{0}^{k}-\gamma_{c}^{k}\right)}{\bar{R} T}\left(\frac{1}{R_{A}}-\frac{1}{R_{B}}\right)\right\},
$$


where $R_{A}$ and $R_{B}$ are the radius of A and B NPs. $V_{m}$ is the molar volume for spherical nanoparticle, $\gamma_{c}^{k}$ and $\gamma_{0}^{k}$ are the surface tension of the $\mathrm{Cu}_{6} \mathrm{Sn}_{5}$ crystal plane $\mathrm{k}$ with and without the adsorption of NPs. $\gamma_{0}^{k}-\gamma_{c}^{k}$ term is negative as the adsorption of NPs decreases the surface tension of the growing $\mathrm{Cu}_{6} \mathrm{Sn}_{5}$ crystal plane k. Hence,

$$
K_{R_{A}}^{0}>K_{R_{B}}^{0}
$$

Equation (6) signifies that smaller $\mathrm{ZrO}_{2} \mathrm{~A}$ NPs can be easily adsorbed on the growing $\mathrm{Cu}_{6} \mathrm{Sn}_{5}$ crystal plane and decreases the surface tension of the $\mathrm{Cu}_{6} \mathrm{Sn}_{5}$ crystal plane $\mathrm{k}$ at a larger extent. This can be attributed to the higher surface to volume ratio. Further, for the fixed addition level more $\mathrm{ZrO}_{2} \mathrm{~A}$ NPs gets adsorbed and contribute to higher suppression of the $\mathrm{Cu}_{6} \mathrm{Sn}_{5}$ growth as compared with $\mathrm{ZrO}_{2} \mathrm{~B}$ NPs (Figure $4 \mathrm{~d}$ ).

\subsection{Effect of $\mathrm{ZrO}_{2}$ NPs Size on the $\mathrm{Cu}_{6} \mathrm{Sn}_{5}$ aging Kinetics in SAC 305/Cu Shear Joints}

Figure 5a-c displays the morphology and Cu-Sn IMC thickness of the monolithic SAC 305/Cu, SAC $305-\mathrm{ZrO}_{2} \mathrm{~A} / \mathrm{Cu}$ and $\mathrm{SAC} 305-\mathrm{ZrO}{ }_{2} \mathrm{~B} / \mathrm{Cu}$ joints subjected to $175^{\circ} \mathrm{C}$ isothermal aging for 24,48 , 144 and $256 \mathrm{~h}$. As can be seen from Figure 5, overall Cu-Sn IMC thickness increases with aging time in the monolithic as well as $\mathrm{ZrO}_{2}$ reinforced SAC 305/Cu joints. However, increase in Cu-Sn IMC thickness appears to be more in monolithic SAC 305/Cu interface. Further, compared with the as-reflow condition, $\mathrm{Cu}_{6} \mathrm{Sn}_{5} \mathrm{IMC}$ morphology transformed from a scallop to planar type with aging. When $\mathrm{Cu}$ atoms diffuse towards the bulk solder, channels between the scallop shaped $\mathrm{Cu}_{6} \mathrm{Sn}_{5}$ provides a shorter diffusion path. Hence the growth rate is rapid at the channels resulting in planarization of $\mathrm{Cu}_{6} \mathrm{Sn}_{5}$ at the interface upon aging [22]. Besides that, $\mathrm{Cu}_{3} \mathrm{Sn}$ phase (dark grey contrast) having planar morphology emerges near to the $\mathrm{Cu}$ side in the monolithic as well as $\mathrm{ZrO}_{2}$ reinforced SAC305/Cu joints. With prolonged aging time (24 to $256 \mathrm{~h}$ ), the overall thickness of IMC increases and $\mathrm{Cu}_{3} \mathrm{Sn}$ phase grows at an expense of $\mathrm{Cu}_{6} \mathrm{Sn}_{5}$. During aging, $\mathrm{Cu}_{6} \mathrm{Sn}_{5}$ phase transforms into $\mathrm{Cu}_{3} \mathrm{Sn}$ phase near to the $\mathrm{Cu}$ through the reaction $(7)[10,23]$ :

$$
C u_{6} S n_{5}+9 C u \rightarrow 5 C u_{3} S n
$$

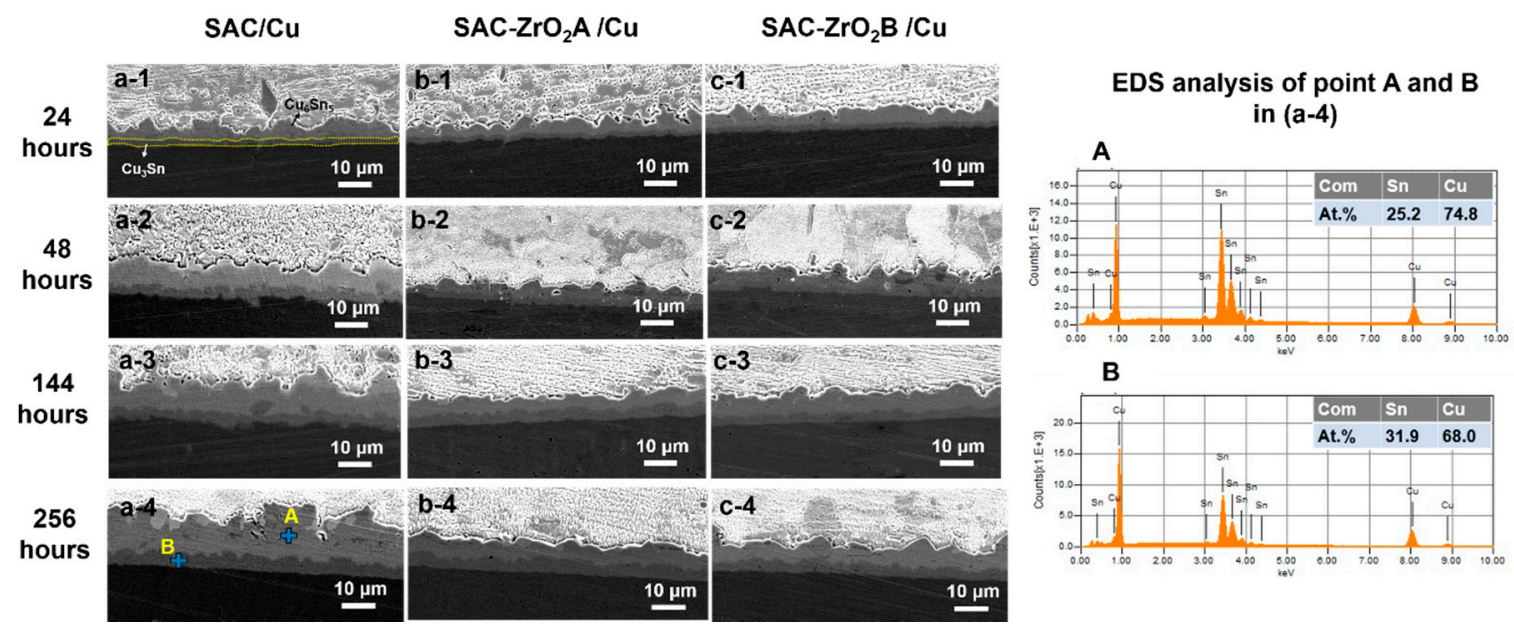

Figure 5. SEM micrograph of $\mathrm{Cu}-\mathrm{Sn}$ IMC layer at the interface of the $175^{\circ} \mathrm{C}$ isothermally aged (a) SAC $305 / \mathrm{Cu}$, (b) SAC 305-ZrO2A/Cu and (c) SAC 305-ZrO2B/Cu joints for various aging time, A, B are the EDS analysis of points A, B in figure (a-4)

The IMC growth kinetics at the solder/Cu interface can be expressed using an empirical power-law relationship $[5,10,24]$ :

$$
X=X_{0}+\sqrt{D t},
$$


where $X$ is the measured $\mathrm{Cu}$-Sn IMC thickness and $X_{0}$ is the initial Cu-Sn IMC thickness after the re-flow, $\mathrm{D}$ is the diffusion coefficient of the diffusing atoms which determines the growth rate, $\mathrm{t}$ is the aging time.

The value of $D$ can be obtained from the linear regression analysis of $X$ versus $t^{1 / 2}$ plot [10]. $\mathrm{Cu}$-Sn IMC thickness versus $\mathrm{t}$ and $\mathrm{t}^{1 / 2}$ plots are shown in Figure $6 \mathrm{a}$ and $\mathrm{b}$ respectively. As seen from Figure 6a, the thickness of $\mathrm{Cu}$-Sn IMC increases with the aging time in all the SAC 305/Cu joints investigated here. Upon aging, $\mathrm{Cu}-\mathrm{Sn} \mathrm{IMC}$ growth appears to be higher for monolithic, followed by $\mathrm{ZrO}_{2} \mathrm{~B}$ reinforced SAC solder. While, $\mathrm{SAC} 305-\mathrm{ZrO}{ }_{2} \mathrm{~A} / \mathrm{Cu}$ joints experienced slower $\mathrm{Cu}-\mathrm{Sn}$ growth upon aging. With increasing aging time from 0 to $256 \mathrm{~h}$, the IMC thickness increases from $2.6 \pm 0.9 \mu \mathrm{m}$ to $16.2 \pm 0.3 \mu \mathrm{m}, 1.7 \pm 0.5 \mu \mathrm{m}$ to $9.6 \pm 0.8 \mu \mathrm{m}$ and from $2.1 \pm 0.7 \mu \mathrm{m}$ to $10.2 \pm 0.3 \mu \mathrm{m}$ for monolithic $\mathrm{SAC} 305 / \mathrm{Cu}, \mathrm{SAC} 305-\mathrm{ZrO}_{2} \mathrm{~A} / \mathrm{Cu}$ and $\mathrm{SAC} 305-\mathrm{ZrO}_{2} \mathrm{~B} / \mathrm{Cu}$ joints respectively. In all the joints, thickness of $\mathrm{Cu}$-Sn IMC exhibited a parabolic relationship with the aging time signifying a diffusion-controlled growth as observed by Deng et al. [22]. The D values for SAC 305/Cu, SAC 305- $\mathrm{ZrO}_{2} \mathrm{~A} / \mathrm{Cu}$ and SAC $305-\mathrm{ZrO}_{2} \mathrm{~A} / \mathrm{Cu}$ joints calculated from the $\mathrm{Cu}-\mathrm{Sn}$ IMC thickness versus $\mathrm{t}^{1 / 2}$ plot as shown in Figure $6 \mathrm{~b}$ are $1.74 \times 10^{-16} \mathrm{~m} / \mathrm{s}, 3.83 \times 10^{-17} \mathrm{~m} / \mathrm{s}$ and $4.99 \times 10^{-17} \mathrm{~m} / \mathrm{s}$ respectively. The $\mathrm{D}$ value for SAC $305 / \mathrm{Cu}$ joint in the present work is close to the D value $\left(1.60 \times 10^{-16} \mathrm{~m} / \mathrm{s}\right)$ reported by Hu et al. [10] for SAC 305/Cu joints aged at $180^{\circ} \mathrm{C}$. Lower $\mathrm{D}$ values obtained for $\mathrm{ZrO}_{2}$ NPs reinforced SAC 305/Cu as compared to monolithic joint suggests that $\mathrm{ZrO}_{2} \mathrm{NPs}$ have hindered the diffusion of $\mathrm{Cu}$ and $\mathrm{Sn}$ atoms during aging. Also, lower D value in $\mathrm{SAC} 305-\mathrm{ZrO}_{2} \mathrm{~A} / \mathrm{Cu}$ joint as compared to $\mathrm{SAC} 305-\mathrm{ZrO}_{2} \mathrm{~B} / \mathrm{Cu}$ joint shows smaller NPs have effectively controlled the $\mathrm{Cu}$ and $\mathrm{Sn}$ diffusion during aging.
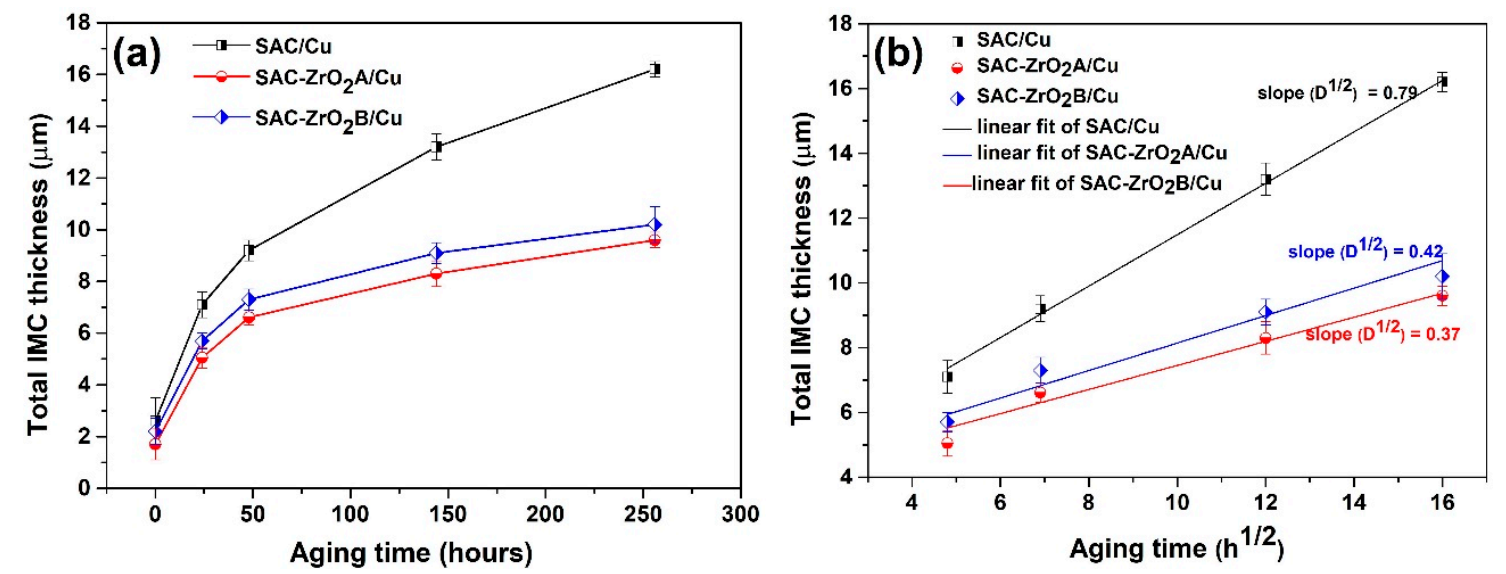

Figure 6. Plots of Total Cu-Sn IMC thickness versus (a) aging time and (b) square root of the aging time at $175^{\circ} \mathrm{C}$ isothermal aging condition.

\subsection{Effect of $\mathrm{ZrO}_{2}$ Nanoparticle Size on the Shear Strength and Fracture Behavior of SAC 305/Cu Interface}

Solder joints are often subjected to mechanical loading in actual service conditions, therefore to analyze and understand the $\mathrm{ZrO}_{2} \mathrm{NPs}$ size on the reliability of the SAC 305/Cu joints, single lap shear tests have been carried out for $\mathrm{ZrO}_{2} \mathrm{~A}$ and $\mathrm{ZrO}_{2} \mathrm{~B}$ reinforced SAC 305/Cu joints. Figure 7 displays the shear strength of monolithic SAC 305/Cu, SAC 305- $\mathrm{ZrO}_{2} \mathrm{~A} / \mathrm{Cu}$ and $\mathrm{SAC} 305-\mathrm{ZrO}_{2} \mathrm{~B} / \mathrm{Cu}$ solder joints in as-reflowed and in $175^{\circ} \mathrm{C}$ isothermal aged condition. In general, deterioration in shear strength is noticed for all the solder joints with aging time. The average shear strength conducted on the as-reflowed monolithic SAC 305/Cu, SAC 305- $\mathrm{ZrO}_{2} \mathrm{~A} / \mathrm{Cu}$ and SAC $305-\mathrm{ZrO}_{2} \mathrm{~B} / \mathrm{Cu}$ joints in as-reflowed condition are $35.9 \pm 1.9 \mathrm{MPa}, 39.7 \pm 1.9 \mathrm{MPa}$ and $38.9 \pm 1.32 \mathrm{MPa}$ respectively. In isothermal aging condition, $\mathrm{ZrO}_{2} \mathrm{NPs}$ added SAC 305/Cu joints revealed higher shear strength as compared to the monolithic SAC 305/Cu. In particular, $\mathrm{ZrO}_{2} \mathrm{~A}$ reinforced SAC 305/Cu joints exhibited better strength as compared to the $\mathrm{ZrO}_{2} \mathrm{~B}$ reinforced SAC 305/Cu joints. After $144 \mathrm{~h}$ of isothermal aging, $\mathrm{ZrO}_{2} \mathrm{~A}$ NPs 
reinforced SAC 305/Cu joints appear to retain the shear strength ( $35.4 \pm 0.97 \mathrm{MPa})$ equivalent to the shear strength exhibited by the monolithic SAC 305/Cu joints in as-reflow condition.

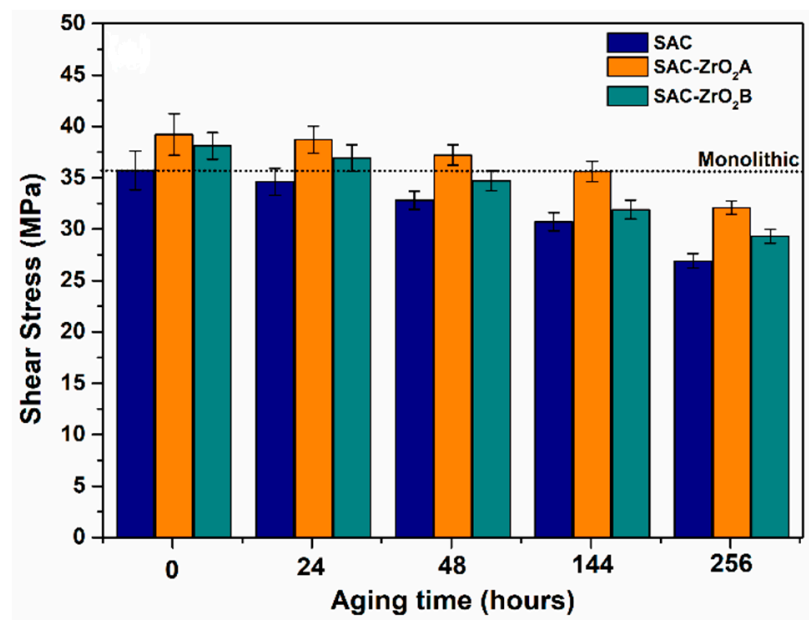

Figure 7. Shear strength of SAC $305 / \mathrm{Cu}$, SAC $305-\mathrm{ZrO}_{2} \mathrm{~A} / \mathrm{Cu}$ and $\mathrm{SAC} 305-\mathrm{ZrO}{ }_{2} \mathrm{~B} / \mathrm{Cu}$ joints in as-reflowed and in $175{ }^{\circ} \mathrm{C}$ isothermal aged condition.

Increase in shear strength for the solder joints has been reported for the addition of CoPd [25], $\mathrm{ZrO}_{2}$ [9], $\mathrm{Al}_{2} \mathrm{O}_{3}$ [26] and $\mathrm{SiC}$ [18] NPs. Higher shear strength in nanocomposite solder joints can be attributed to three factors: (a) presence of NPs and their dispersion strengthening, (b) finely dispersed $\mathrm{Ag}_{3} \mathrm{Sn}$ IMC particles in the solder matrix and (c) suppressed $\mathrm{Cu}_{6} \mathrm{Sn}_{5} \mathrm{IMC}$ at the solder/Cu joint interface [27]. The presence of $\mathrm{ZrO}_{2} \mathrm{NPs}$ and $\mathrm{Ag}_{3} \mathrm{Sn}$ IMC in solder strengthen the matrix by (a) generating geometrically necessary dislocations in the matrix in order to balance the co-efficient of expansion difference and elastic modulus difference between the matrix and the particle $\left(\mathrm{ZrO}_{2} \mathrm{NPs}\right.$ and $\mathrm{Ag}_{3} \mathrm{Sn}$ ) and (b) obstructing the dislocation movement [5,27]. Additionally, refined $\mathrm{Ag}_{3} \mathrm{Sn}$ IMC in the matrix of $\mathrm{ZrO}_{2}$ added SAC 305 solder contribute to the strengthening through load-transferring mechanism. Good interface bonding between the dispersed particles and matrix contribute to a better load transferring ability [27]. The yield stress of the alloy due to the piling of dislocations upon load transfer depends on the spacing between the dispersed particles and is given by [17]:

$$
\tau_{0}=\sqrt{\frac{G b \tau}{\pi v L}}
$$

where $G$ is the shear elastic modulus of the substrate; $b$ is the Burgers vector; $v$ is the Poisson's ratio; $\tau$ is the fracture stress of $\mathrm{Ag}_{3} \mathrm{Sn}$ particles and $L$ is the average spacing between the $\mathrm{Ag}_{3} \mathrm{Sn}$ particles.

From Equation (9), smaller spacing between $\mathrm{Ag}_{3} \mathrm{Sn}$ IMC yields better load-transfer ability. In the present work, the average spacing between $\mathrm{Ag}_{3} \mathrm{Sn}$ IMC particles in the monolithic SAC 305 solder is $2.4 \pm 0.7 \mu \mathrm{m}$. With the addition of $\mathrm{ZrO}_{2} \mathrm{~A}$ and $\mathrm{ZrO}_{2} \mathrm{~B}$ NPs, the average spacing between $\mathrm{Ag}_{3} \mathrm{Sn}$ particles reduce to $0.46 \pm 0.06 \mu \mathrm{m}$ and $1.1 \pm 0.2 \mu \mathrm{m}$ respectively (Table 1). According to Equation (9), the ratio of $L_{S A C} / L_{S A C-Z r O_{2} A}$ for SAC $305-Z_{r O} A / C u$ joint is 4.2 , hence $\tau_{S A C-Z \mathrm{ZO}_{2} A} / \tau_{S A C}=\mathbf{2 . 0}$. For SAC $305-\mathrm{ZrO}_{2} \mathrm{~B} / \mathrm{Cu}$ joint, the ratio of $L_{S A C} / L_{S A C-Z \mathrm{ZrO}_{2} B}$ decreases to 2.6 , hence $\tau_{S A C-\mathrm{ZrO}_{2} B} / \tau_{S A C}=\mathbf{1 . 6}$. The calculated yield stress by load transfer mechanism for $\mathrm{SAC} 305-\mathrm{ZrO}{ }_{2} \mathrm{~A} / \mathrm{Cu}$ joints is double than that of SAC 305- $\mathrm{ZrO}_{2} \mathrm{~B} / \mathrm{Cu}$. In consistent with the theoretical Equation (9), higher shear strength observed for as-reflow SAC $305-\mathrm{ZrO}_{2} \mathrm{~A} / \mathrm{Cu}$ joints can be attributed to the reduced $\mathrm{Ag}_{3} \mathrm{Sn} \mathrm{IMC}$ spacing in the solder matrix.

Decrease in shear strength after aging can be related to two factors: (a) growth of $\mathrm{Cu}_{3} \mathrm{Sn}$ and $\mathrm{Cu}_{6} \mathrm{Sn}_{5} \mathrm{IMC}^{\prime} \mathrm{s}$ at the interface and (b) coarsening of $\mathrm{Ag}_{3} \mathrm{Sn}$ IMC in the solder matrix [22,28]. As can be seen from the thickness plot (Figure 6a), the difference in the average Cu-Sn IMC thickness for the $256 \mathrm{~h}$ 
aged SAC $305-\mathrm{ZrO}_{2} \mathrm{~A} / \mathrm{Cu}$ and $\mathrm{SAC} 305-\mathrm{ZrO}_{2} \mathrm{~B} / \mathrm{Cu}$ joints is minor and hence cannot be considered as a significant factor for the difference in shear strength. Yang et al. [29] reported that thicker intermetallic layer corresponding to a higher reflow time does not decrease the shear strength as remarkably as thermal aging. It was reported that degradation in shear strength of aged SAC solder corresponds to the $\mathrm{Ag}_{3} \mathrm{Sn}$ IMC coarsening in the solder matrix rather than the growth of Cu-Sn IMC thickness at the interface [22]. However, thick IMC layer can be a potential source of cracks [22]. Coarsening of $\mathrm{Ag}_{3} \mathrm{Sn}$ IMC during thermal aging are controlled by Ostwald ripening where the smaller IMC dissolves in Sn-rich matrix, diffuse towards energetically favorable $\mathrm{Ag}_{3} \mathrm{Sn}$ and re-precipitate resulting in the growth of the $\mathrm{Ag}_{3} \mathrm{Sn}$ IMC size [30].

Figure $8 \mathrm{a}, \mathrm{b}$ displays the microstructure of $48 \mathrm{~h}$ aged $\mathrm{SAC} 305-\mathrm{ZrO}{ }_{2} \mathrm{~A} / \mathrm{Cu}$ and $\mathrm{SAC} 305-\mathrm{ZrO}_{2} \mathrm{~B} / \mathrm{Cu}$ joints respectively. The morphology of $\beta$-Sn grains were transformed from dendritic to equiaxed with definite grain boundaries. Figure $8 \mathrm{c}-\mathrm{f}$ shows the magnified microstructure of $\mathrm{ZrO}_{2} \mathrm{~A}$ and $\mathrm{ZrO}_{2} \mathrm{~B}$ reinforced SAC 305/Cu joints after 48 and $256 \mathrm{~h}$ of aging. $\mathrm{Ag}_{3} \mathrm{Sn}$ IMC can be seen with light-grey contrast. Compared with the as-reflow condition (see Figure 3), $\mathrm{Ag}_{3} \mathrm{Sn}$ IMC coarsened and their fraction decreased upon $48 \mathrm{~h}$ of aging. This is consistent with dissolution and re-precipitation of $\mathrm{Ag}_{3} \mathrm{Sn}$ reported in the previous reports [30,31] Further, coarsening of $\mathrm{Ag}_{3} \mathrm{Sn}$ IMC appears to be higher for SAC 305- $\mathrm{ZrO}_{2} \mathrm{~B} / \mathrm{Cu}$ joint. $\mathrm{ZrO}_{2}$ A NPs dispersed in the solder matrix have contributed to a finer $\mathrm{Ag}_{3} \mathrm{Sn}$ re-precipitation upon aging and thereby responsible for their higher shear strength.

Figure 9 shows the top view of the fractured surface of as-reflowed and aged SAC $305-\mathrm{ZrO}_{2} \mathrm{~A} / \mathrm{Cu}$ joints after the shear test. When tensile or shear tests are conducted on solder joints, fracture propagation mainly occurs in three general modes [22,32-34]. Mode 1-A typical ductile fracture where the cracks start at the solder/Cu joint and propagates within the solder. The fractured surface is completely covered with bulk solder. Mode 2-A ductile-brittle mixed fracture mode where the crack starts at the joint interface, initially propagates across the solder and then along the IMC. The surface fractured by mode 2 exhibits bulk solder as well as few exposed IMC. Mode 3-A brittle mode wherein the cracks begin and propagate along the IMC layer and fracture occurs completely in the interfacial IMC layer. The fractured surface with mode 3 failure shows only brittle IMC. From Figure $9 a-d$, it is clear that the as-reflowed and aged SAC $305-\mathrm{ZrO}_{2} \mathrm{~A} / \mathrm{Cu}$ joints retained a ductile fracture mode in the solder region as evidenced from the plastic deformation and dimples along the shear direction. Dimples are formed as a result of coalescence of micro voids during plastic deformation [35]. As a consequence, solder surface tear along the shear direction resulting in tear ridges [34]. Also, in accordance with the earlier reports [36-38], the dimple size increases significantly with the aging time as seen in Figure 9b-d. With increased aging time of $256 \mathrm{~h}$, although most locations of fractures surfaces are covered with solder, few $\mathrm{Cu}_{6} \mathrm{Sn}_{5}$ regions were exposed in some incidences as shown Figure 9d. Magnified image in Figure 9e shows the crack propagating along the $\mathrm{Cu}_{6} \mathrm{Sn}_{5} \mathrm{IMC}$ beneath the solder. This indicates that fracture has occurred close to the solder/IMC interface. Upon shearing, solder/IMC interface experiences the maximum concentration of stress and becomes a preferred site for the onset of crack. Further, the combination of thick IMC along the interface and the lower fracture toughness of IMC $\left(\mathrm{Cu}_{6} \mathrm{Sn}_{5}\right.$ and $\left.\mathrm{Cu}_{3} \mathrm{Sn}\right)$ makes the interface a preferred location for the crack propagation [23]. Therefore, the localized shear occurring along the solder close to the IMC interface results in the fracture which agreed well with the previous reports [22,34]. 

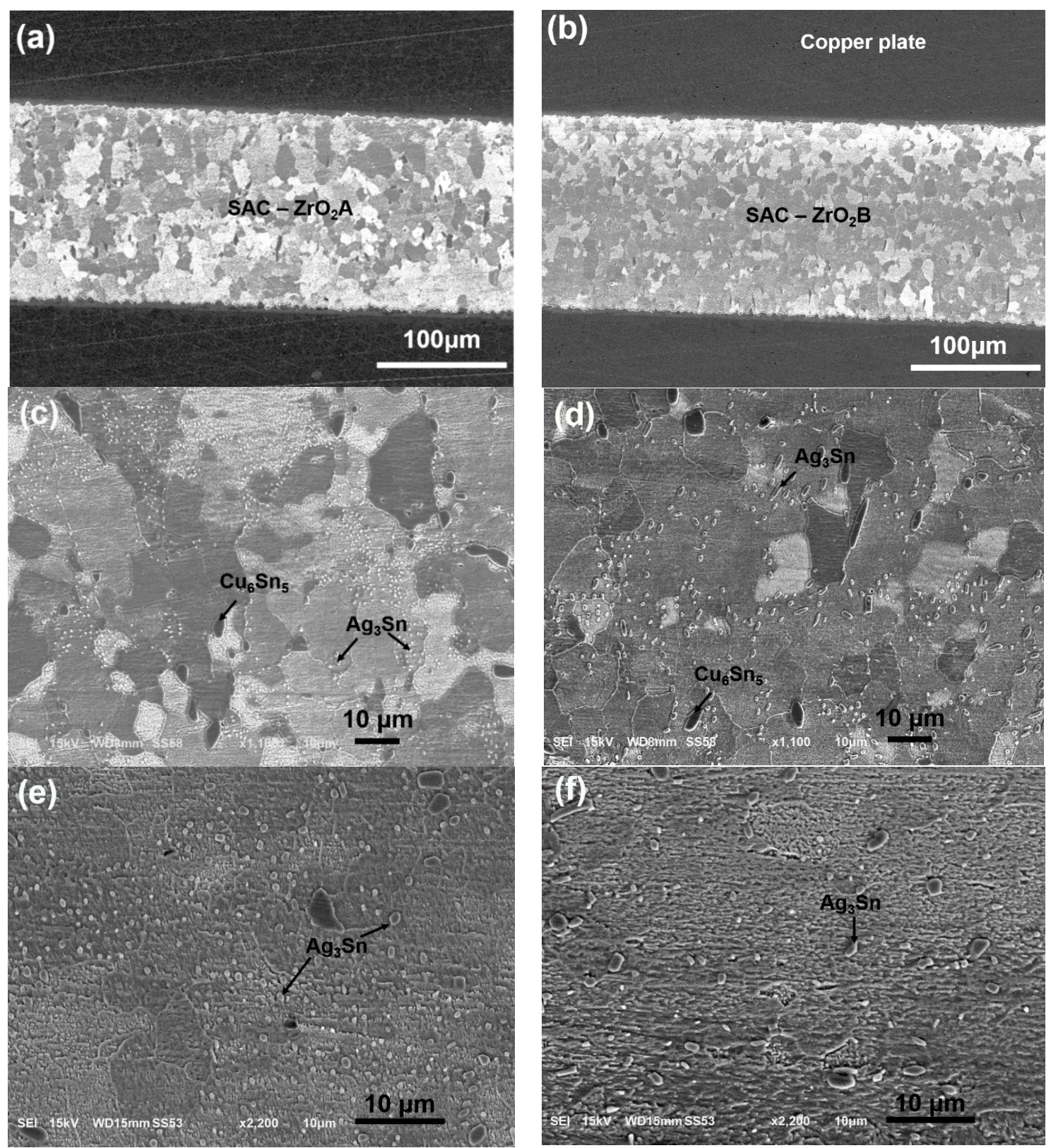

Figure 8. (a-d) SEM micrograph of $48 \mathrm{~h}$ isothermally aged joints. (a) $\mathrm{SAC} 305-\mathrm{ZrO} \mathrm{O}_{2} \mathrm{~A} / \mathrm{Cu}$ joint and (c) the corresponding microstructure, (b) SAC $305-\mathrm{ZrO}_{2} \mathrm{~B} / \mathrm{Cu}$ joint and (d) the corresponding microstructure. (e,f) microstructure of $256 \mathrm{~h}$ isothermally aged $\mathrm{SAC} 305-\mathrm{ZrO}_{2} \mathrm{~A} / \mathrm{Cu}$ joint and SAC $305-\mathrm{ZrO}_{2} \mathrm{~B} / \mathrm{Cu}$ joints respectively. 

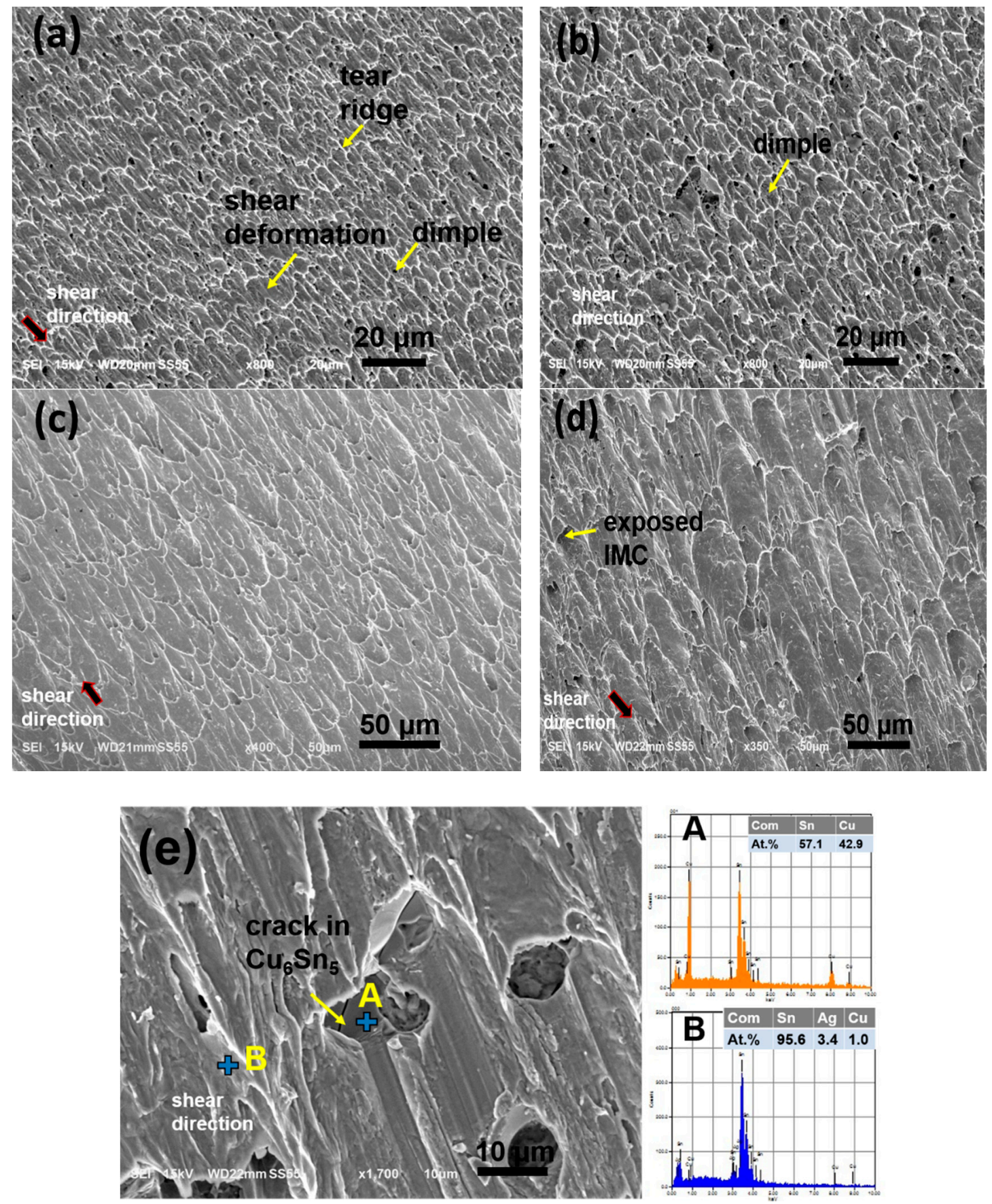

Figure 9. Fractured surfaces of (a) as-reflowed and (b-e) isothermally aged SAC 305- $\mathrm{ZrO} 2 \mathrm{~A} / \mathrm{Cu}$ joint for various aging time: (b) 48 h, (c) $144 \mathrm{~h},(\mathbf{d}, \mathbf{e}) 256 \mathrm{~h}, \mathrm{~A}, \mathrm{~B}$ are the EDS analysis corresponding to the points $\mathrm{A}$ and $\mathrm{B}$ in figure (e).

Figure $10 \mathrm{a}-\mathrm{b}$ shows the top view of the fractured surface and the crack propagation in $256 \mathrm{~h}$ aged SAC $305-\mathrm{ZrO}_{2} \mathrm{~A} / \mathrm{Cu}$ and $\mathrm{SAC} 305-\mathrm{ZrO}_{2} \mathrm{~B} / \mathrm{Cu}$ joints respectively. Apparently, crack propagation in the solder and interfacial IMC signifies a mixed fracture mode. Thicker Cu-Sn IMC after $256 \mathrm{~h}$ aging shares a weaker interface with the solder. Additionally, formation of Kirkendall voids (circled in Figure 10a,b) upon aging also degrades the fracture toughness of the IMC layer [39]. Clearly most of the locations in the fractured IMC region displayed a broken grain with a brittle cleavage plane. It was confirmed from the EDS analysis (Figure 10c) that the broken grains were $\mathrm{Cu}_{6} \mathrm{Sn}_{5}$. The exposed columnar grains adjacent to the $\mathrm{Cu}_{6} \mathrm{Sn}_{5}$ grains were identified as $\mathrm{Cu}_{3} \mathrm{Sn}$ from the EDS as shown in 
Figure 10d. This shows that intergranular fracture had occurred between the $\mathrm{Cu}_{6} \mathrm{Sn}_{5}$ and $\mathrm{Cu}_{3} \mathrm{Sn}$ grains in the IMC region and cleavage fracture has happened within the $\mathrm{Cu}_{6} \mathrm{Sn}_{5}$ grains.

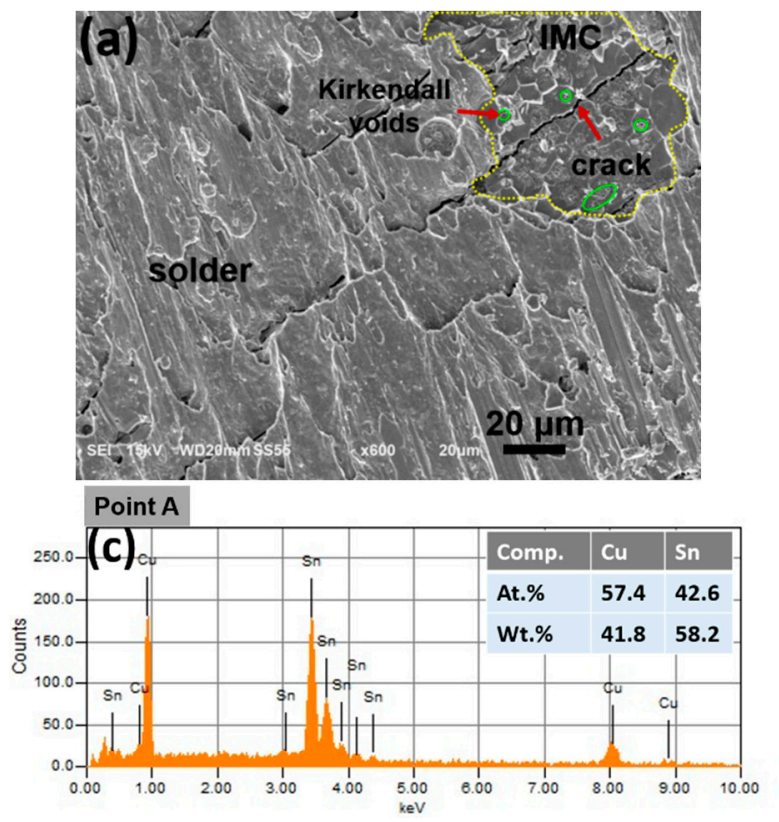

(e) Ductile fracture Fracture surface - bulk solder

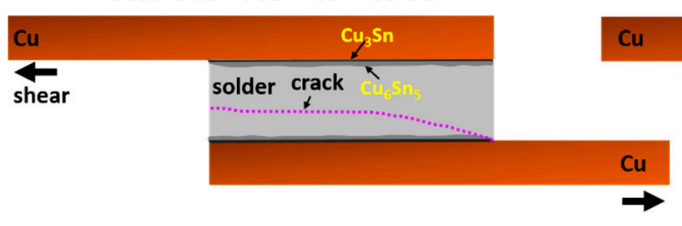

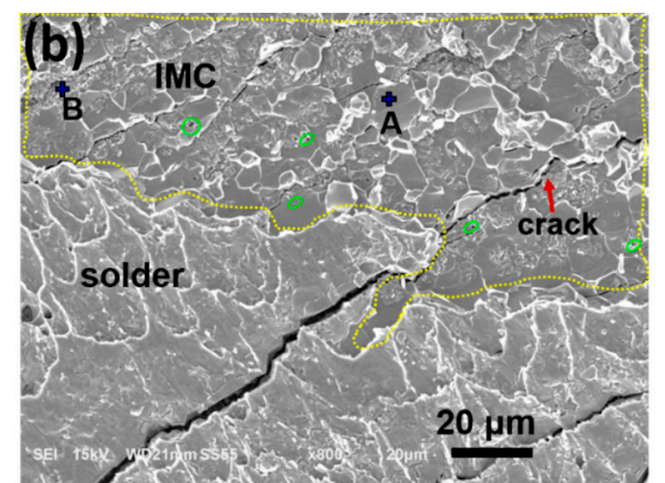

Point B

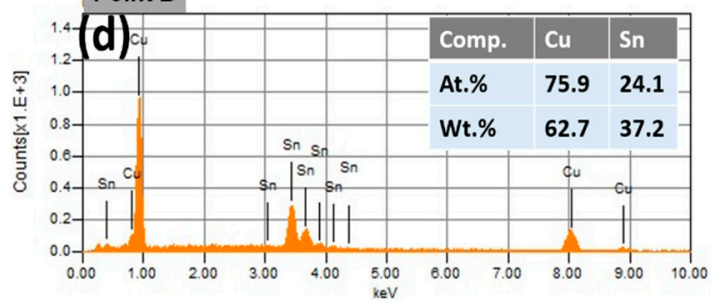

Mixed fracture

Fracture surface -solder/Cu-Sn IMC

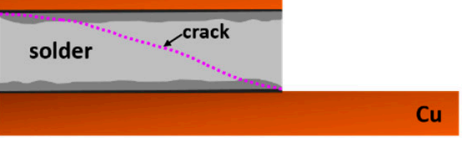

Figure 10. Solder/IMC fracture and crack propagation in $256 \mathrm{~h}$ isothermally aged (a) $\mathrm{SAC} 305-\mathrm{ZrO}_{2} \mathrm{~A} / \mathrm{Cu}$ joint, (b) SAC 305- $\mathrm{ZrO}_{2} \mathrm{~B} / \mathrm{Cu}$ joint, (c,d) EDS analysis corresponding to points A and B in (b), (e) schematic illustration of the fracture modes.

In summary, the fracture occurred predominantly within the bulk solder for $\mathrm{ZrO}_{2} \mathrm{NPs}$ reinforced SAC 305/Cu joints until $144 \mathrm{~h}$ of isothermal aging. However, the fracture surfaces of $256 \mathrm{~h}$ aged joints exhibited a mixed solder/IMC mode. Schematic illustrations of ductile and mixed fracture modes is shown in schematically in Figure 10e. The ductile to mixed transition at higher aging time can be attributed to coarsening of $\mathrm{Ag}_{3} \mathrm{Sn}$ precipitates, Kirkendall voids and increase in IMC thickness. Based on the observations, it can be interpreted that the higher shear strength displayed by SAC $305-\mathrm{ZrO}_{2} \mathrm{~A} / \mathrm{Cu}$ joints after $256 \mathrm{~h}$ aging can be attributed to the presence of fine $\mathrm{Ag}_{3} \mathrm{Sn}$ IMC within the bulk solder. Therefore, bulk solder close to $\mathrm{SAC} 305-\mathrm{ZrO}_{2} \mathrm{~A} / \mathrm{Cu}$ interface can experience higher shear stress as compared to $\mathrm{SAC} 305-\mathrm{ZrO}_{2} \mathrm{~B} / \mathrm{Cu}$.

\section{Conclusions}

The present work reports the microstructure, mechanical and IMC growth kinetics in aged SAC 305/Cu joints reinforced with two $\mathrm{ZrO}_{2}$ NPs having different particle sizes. A smaller $\mathrm{ZrO}_{2} \mathrm{~A}$ NPs having an average particle size of 5-15 nm and relatively larger $\mathrm{ZrO}_{2} \mathrm{~B} N$ Ps having an average particle size of 70-90 nm and $0.2 \mathrm{wt} . \%$ of $\mathrm{ZrO}_{2} \mathrm{~A}$ and $\mathrm{B}$ nanocomposite solders were successfully prepared by a mechanical mixing method. Single lap shear joints were fabricated from the as-prepared $\mathrm{ZrO}_{2}$ nanocomposite solder paste and isothermally aged at $175^{\circ} \mathrm{C}$ for $24,48,144$ and $256 \mathrm{~h}$. The conclusions are drawn as follows: 
(1). Microstructure of the as-reflow nanocomposite $\mathrm{SAC} 305-\mathrm{ZrO}_{2} / \mathrm{Cu}$ joints exhibited higher eutectic area with refined $\beta-S n$ grain and $\mathrm{Ag}_{3} \mathrm{Sn}$ IMC as compared to the monolithic SAC 305/Cu joints. In particular, $\mathrm{ZrO}_{2}$ A NPs addition has contributed to a finer $\beta-\mathrm{Sn}$ and $\mathrm{Ag}_{3} \mathrm{Sn}$ grain size of $3.5 \pm 2.0 \mu \mathrm{m}$ and $0.41 \pm 0.03 \mu \mathrm{m}$ respectively with higher eutectic area as compared to the $\mathrm{ZrO}_{2} \mathrm{~B}$.

(2). NPs in the SAC solder suppressed the thickness of $\mathrm{Cu}_{6} \mathrm{Sn}_{5} \mathrm{IMC}$ at the interface from $2.6 \pm 0.9 \mu \mathrm{m}$ in monolithic to $1.7 \pm 0.5 \mu \mathrm{m}$ and $2.1 \pm 0.7 \mu \mathrm{m}$ for SAC $305-\mathrm{ZrO}_{2} \mathrm{~A} / \mathrm{Cu}$ and $\mathrm{SAC} 305-\mathrm{ZrO}_{2} \mathrm{~B} / \mathrm{Cu}$ joint respectively.

(3). For all the investigated samples, IMC thickness increased linearly with the square root of aging time and the growth kinetics followed empirical-power law, indicating diffusion-controlled IMC growth. Addition of $\mathrm{ZrO}_{2}$ NPs decreased the diffusion coefficient remarkably. Notably, $\mathrm{ZrO}_{2} \mathrm{~A}$ added SAC 305/Cu joint displayed the smallest diffusion co-efficient of $3.83 \times 10^{-17} \mathrm{~m} / \mathrm{s}$. This is due to the presence of higher number of $\mathrm{ZrO}_{2} \mathrm{NPs}$ effectively blocking the diffusion of $\mathrm{Cu}$ and $\mathrm{Sn}$ at the interface

(4). SAC $305-\mathrm{ZrO}_{2} \mathrm{~A} / \mathrm{Cu}$ joints exhibited highest shear strength of $39.7 \pm 1.9 \mathrm{MPa}$ in the as-reflow condition owing to finer $\mathrm{Ag}_{3} \mathrm{Sn}$ IMC with reduced spacing as compared to $\mathrm{SAC} 305-\mathrm{ZrO}_{2} \mathrm{~A} / \mathrm{Cu}$ joints. Generally, the shear strength of all joints decreased with the aging time. The decline in shear strengths upon aging can be related with the coarsening of $\mathrm{Ag}_{3} \mathrm{Sn}$ and the growth of $\mathrm{Cu}-\mathrm{Sn}$ IMC at the interface. $\mathrm{ZrO}_{2} \mathrm{~A}$ added SAC 305/Cu joint exhibited highest shear strength of after $256 \mathrm{~h}$ of aging due to the presence of fine $\mathrm{Ag}_{3} \mathrm{Sn}$ precipitates in the bulk solder.

(5). Fracture analysis shows a ductile fracture mode for all the $\mathrm{SAC} 305-\mathrm{ZrO}_{2} \mathrm{~A} / \mathrm{Cu}$ until $144 \mathrm{~h}$ of aging. After $256 \mathrm{~h}$ of aging, both SAC $305-\mathrm{ZrO}_{2} \mathrm{~A} / \mathrm{Cu}$ and $\mathrm{SAC} 305-\mathrm{ZrO}_{2} \mathrm{~B} / \mathrm{Cu}$ joints fractured by mixed fracture mode at the solder/IMC interface.

Therefore, to enhance the effectiveness of nanocomposite solders in the expanding electronic era, it is beneficial to consider nanoparticle size as a material design parameter along with nanoparticle type and addition level.

Author Contributions: Conceptualization, methodology, S.H.R.; formal analysis, writing-original draft preparation, S.H.R.; review and editing, J.P.J.; supervision, J.P.J.; analysis, project administration, S.J.H.; funding acquisition, J.P.J. All authors have read and agreed to the published version of the manuscript.

Funding: This work was supported by the Materials Parts Technology Development Program, (Project number: 20010580), Development of conductive nanomaterial technology for fine electrode junction of mini-LED, Funded by the Ministry of Trade, Industry \& Energy (MI), Korea.

Conflicts of Interest: The authors declare no known financial and personal relationships that could have appeared to influence this work.

\section{References}

1. Pu, L.; Liu, Y.; Yang, Y.; He, Q.; Zhou, Z.; Zhao, X.; Tan, C.; Tu, K.N. Effect of adding Ag to the medium entropy SnBiIn alloy on intermetallic compound formation. Mater. Lett. 2020, 272, 1-4. [CrossRef]

2. Pu, L.; He, Q.; Yang, Y.; Zhao, X.; Hou, Z.; Tu, K.N.; Liu, Y. The microstructure and mechanical property of the high entropy alloy as a low temperature solder. In Proceedings of the 2019 IEEE 69th Electronic Components and Technology Conference, Las Vegas, NV, USA, 28-31 May 2019; pp. 1716-1721. [CrossRef]

3. Kotadia, H.R.; Howes, P.D.; Mannan, S.H. A review: On the development of low melting temperature Pb-free solders. Microelectron. Reliab. 2014, 54, 1253-1273. [CrossRef]

4. Jiang, N.; Zhang, L.; Liu, Z.; Sun, L.; Long, W.; He, P.; Xiong, M.; Zhao, M. Reliability issues of lead-free solder joints in electronic devices. Sci. Technol. Adv. Mat. 2019, 20, 876-901. [CrossRef] [PubMed]

5. Tsao, L.C. Suppressing effect of $0.5 \mathrm{wt}$ \% nano-TiO2 addition into Sn-3.5Ag-0.5Cu solder alloy on the intermetallic growth with $\mathrm{Cu}$ substrate during isothermal aging. J. Alloys Compds. 2011, 509, 8441-8448. [CrossRef]

6. Chuang, T.H.; Wu, M.W.; Chang, S.Y.; Ping, S.F.; Tsao, L.C. Strengthening mechanism of nano- $\mathrm{Al}_{2} \mathrm{O}_{3}$ particles reinforced Sn3.5Ag0.5Cu lead-free solder. J. Mater. Sci. Mater. Electron. 2011, 22, 1021-1027. [CrossRef] 
7. Jung, D.H.; Sharma, A.; Lim, D.U.; Yun, J.H.; Jung, J.P. Effects of AlN Nanoparticles on the Microstructure, Solderability, and Mechanical Properties of Sn-Ag-Cu Solder. Metall. Mater. Trans. A 2017, 48, 4372-4384. [CrossRef]

8. Babaghorbani, P.; Nai, S.M.L.; Gupta, M. Development of lead-free $\mathrm{Sn}-3.5 \mathrm{Ag} / \mathrm{SnO}_{2}$ nanocomposite solders. J. Mater. Sci. Mater. Electron. 2008, 20, 571-576. [CrossRef]

9. Shen, J.; Liu, Y.C.; Han, Y.J.; Tian, Y.M.; Gao, H.X. Strengthening effects of $\mathrm{ZrO}_{2}$ nanoparticles on the microstructure and microhardness of Sn-3.5Ag lead-free solder. J. Electron. Mater. 2006, 35, 1672-1679. [CrossRef]

10. Hu, X.; Xu, T.; Keer, L.M.; Li, Y.; Jiang, X. Microstructure evolution and shear fracture behavior of aged Sn3Ag0. 5Cu/Cu solder joints. Mater. Sci. Eng. A 2016, 673, 167-177. [CrossRef]

11. Huang, M.L.; Yang, F. Size effect model on kinetics of interfacial reaction between Sn-xAg-yCu solders and Cu substrate. Sci. Rep. 2015, 4, 7117. [CrossRef]

12. Chang, S.Y.; Jain, C.C.; Chuang, T.H.; Feng, L.P.; Tsao, L.C. Effect of addition of $\mathrm{TiO}_{2}$ nanoparticles on the microstructure, microhardness and interfacial reactions of Sn3.5AgXCu solder. Mater. Des. 2011, 32, 4720-4727. [CrossRef]

13. Aspalter, A.; Cerny, A.; Göschl, M.; Podsednik, M.; Khatibi, G.; Yakymovych, A.; Plevachuk, Y. Hybrid solder joints: Morphology and shear strength of $\mathrm{Sn}-3.0 \mathrm{Ag}-0.5 \mathrm{Cu}$ solder joints by adding ceramic nanoparticles through flux doping. Appl. Nanosci. 2020, 29, 1-7. [CrossRef]

14. Gain, A.K.; Fouzder, T.; Chan, Y.C.; Yung, W.K.C. Microstructure kinetic analysis and hardness of Sn-Ag-Cu-1 $\mathrm{wt} \%$ nano $\mathrm{ZrO}_{2}$ composite solder on OSP-Cu pads. J. Alloys Compds. 2011, 509, 3319-3325. [CrossRef]

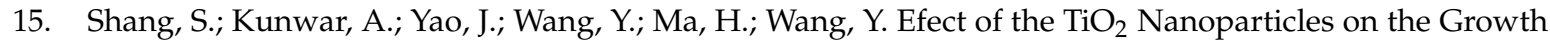
Behavior of Intermetallics in Sn/Cu Solder Joints. Met. Mater. Int. 2019, 25, 499-507. [CrossRef]

16. Sivasubramaniam, V.; Galli, M.; Cugnoni, J.; Janczak-Rusch, J.; Botsis, J. A Study of the Shear Response of a Lead-Free Composite Solder by Experimental and Homogenization Techniques. J. Electron. Mater. 2009, 38, 2122-2131. [CrossRef]

17. Tsao, L.C.; Chang, S.Y.; Lee, C.I.; Sun, W.H.; Huang, C.H. effects of nano- $\mathrm{Al}_{2} \mathrm{O}_{3}$ additions on microstructure development and hardness of Sn3.5Ag0.5Cu solder. Mater. Des. 2010, 31, 4831-4835. [CrossRef]

18. El-Daly, A.A.; Fawzy, A.; Mansour, S.F.; Younis, M.J. Thermal analysis and mechanical properties of An-1.0Ag-0.5Cu solder alloy after modification with SiC anao-sized particles. J. Mater. Sci. Mater. Electron. 2013, 24, 2976-2988. [CrossRef]

19. Shen, J.; Chan, Y.C. Research advances in nano-composite solders. Microelectron. Reliab. 2009, 49, $223-234$. [CrossRef]

20. Xia, Z.; Chen, Z.; Shi, Y.; Mu, N.; Sun, N. Effect of Rare Earth Element Additions on the Microstructure and Mechanical Properties of Tin-Silver-Bismuth Solder. J. Electron. Mater. 2002, 31, 564-567. [CrossRef]

21. Zhang, L.; Tu, K.N. Structure and properties of lead-free solders bearing micro and nano particles. Mater. Sci. Eng. R Rep. 2014, 82, 1-32. [CrossRef]

22. Deng, X.; Sidhu, R.S.; Johnson, P.; Chawla, N. Influence of Reflow and Thermal Aging on the Shear Strength and Fracture Behavior of Sn-3.5Ag Solder/Cu Joints. Metall. Mater. Trans. A 2005, 36, 55-64. [CrossRef]

23. Zuozhu, Y.; Sun, F.; Guo, M. Effect of $\mathrm{Sn} / \mathrm{Cu}$ thickness ratio on the transformation law of $\mathrm{Cu}_{6} \mathrm{Sn}_{5}$ to $\mathrm{Cu}_{3} \mathrm{Sn}$ in $\mathrm{Sn} / \mathrm{Cu}$ interface during aging. Mater. Res. 2018, 5, 086503. [CrossRef]

24. Rizvi, M.J.; Chan, Y.C.; Bailey, C.; Lu, H.; Islam, M.N. Effect of adding 1 wt $\%$ Bi into the $\mathrm{Sn}_{-2.8} \mathrm{Ag}_{-0.5} \mathrm{Cu}$ solder alloy on the intermetallic formations with $\mathrm{Cu}$-substrate during soldering and isothermal aging. J. Alloys Compds. 2006, 407, 208-214. [CrossRef]

25. Yakymovych, A.; Slabon, A.; Švec, P., Sr.; Plevachuk, Y.; Orovcik, L.; Bajana, O. Nanocomposite SAC solders: The effect of adding CoPd nanoparticles on the morphology and the shear strength of the $S n-3.0 \mathrm{Ag}-0.5 \mathrm{Cu} / \mathrm{Cu}$ solder joints. Appl. Nanosci. 2020, 49. [CrossRef]

26. Tsao, L.C.; Wu, R.W.; Cheng, T.H.; Fan, K.H.; Chen, R.S. Effects of nano- $\mathrm{Al}_{2} \mathrm{O}_{3}$ particles on microstructure and mechanical properties of Sn3.5Ag0.5Cu composite solder ball grid array joints on Sn/Cu pads. Mater. Des. 2013, 50, 774-781. [CrossRef]

27. Nai, S.M.L.; Wei, J.; Gupta, M. Interfacial intermetallic growth and shear strength of lead-free composite solder joints. J. Alloys Compds. 2009, 473, 100-106. [CrossRef] 
28. Zhao, D.; Zhang, K.; Ma, N.; Li, S.; Yin, C.; Huo, F. Dynamic Observation of Interfacial IMC Evolution and Fracture Mechanism of Sn2.5Ag0.7Cu0.1RE/Cu Lead-Free Solder Joints during Isothermal Aging. Materials 2020, 13, 831. [CrossRef]

29. Yang, W.; Felton, L.E.; Messler, R.W. The effect of soldering process variables on the microstructure and mechanical properties of eutectic Sn-Ag/Cu solder joints. J. Electron. Mater. 1995, 24, 1465-1472. [CrossRef]

30. Tian, Y.; Ren, N.; Zhao, Z.; Wu, F.; Sitaraman, S.K. $\mathrm{Ag}_{3} \mathrm{Sn}$ compounds coarsening behaviors in Micro-joints. Materials 2018, 11, 2509. [CrossRef]

31. Morando, C.; Fornaro, O.; Garbellini, O.; Palacio, H. Microstructure evolution during the aging at elevated temperature of Sn-Ag-Cu solder alloys. Procedia Mater. Sci. 2012, 1, 80-86. [CrossRef]

32. Mahdavifard, M.H.; Sabri, M.F.M.; Said, S.M.; Rozali, S. High stability and aging resistance Sn-1Ag-0.5Cu solder alloy by Fe and Bi minor alloying. Microelectron. Eng. 2019, 208, 29-38. [CrossRef]

33. An, T.; Qin, F. Effects of the intermetallic compound microstructure on the tensile behavior of $\operatorname{Sn} 3.0 \mathrm{Ag} 0.5 \mathrm{Cu} / \mathrm{Cu}$ solder joint under various strain rates. Microelectron. Reliab. 2014, 54, 932-938. [CrossRef]

34. An, T.; Qin, F. Intergranular cracking simulation of the intermetallic compound layer in solder joints. Comput. Mater. Sci. 2013, 79, 1-14. [CrossRef]

35. Yao, P.; Li, X.; Han, X.; Xu, L. Shear strength and fracture mechanism for full Cu-Sn IMCs solder joints with different $\mathrm{Cu}_{3} \mathrm{Sn}$ proportion and joints with conventional interfacial structure in electronic packaging. Comput. Mater. Sci. 2019, 31, 6-19. [CrossRef]

36. Yang, L.; Ge, J.; Zhang, Y.; Dai, J. Interfacial IMC layer and tensile properites of Ni-reinforced $\mathrm{Cu} / \mathrm{Sn}-0.7 \mathrm{Cu}-0.05 \mathrm{Ni} / \mathrm{Cu}$ solder joint: Effect of aging temerpature. Trans. Indian Inst. Metal. 2017, 70, 2429-2439. [CrossRef]

37. Sujan, G.K.; Haseeb, A.S.M.A.; Nishikawa, H.; Amalina, M.A. Interfacial reaction, ball shear strength and fracture surface analysis of lead-free solder joints prepared using cobalt nanoparticle doped flux. J. Alloys Compds. 2017, 695, 981-990. [CrossRef]

38. Lee, C.B.; Jung, S.B.; Shin, Y.E.; Shur, C.C. Effect of isothermal Aging on the ball shear strength in BGS joints with Sn-3.5Ag-0.75Cu solder. Mater. Trans. 2002, 43, 1858-1863. [CrossRef]

39. Park, J.M.; Kim, S.H.; Jeong, M.H.; Park, Y.B. Effect of $\mathrm{Cu}-\mathrm{Sn}$ intermetallic compound reactions on the Kirkendall void growth characteristics in $\mathrm{Cu} / \mathrm{Sn} / \mathrm{Cu}$ microbumps. Jpn. J. Appl. Phys. 2014, 53, 1-4. [CrossRef]

(C) 2020 by the authors. Licensee MDPI, Basel, Switzerland. This article is an open access article distributed under the terms and conditions of the Creative Commons Attribution (CC BY) license (http://creativecommons.org/licenses/by/4.0/). 